\title{
Social Process on Sexual Behaviour of Dating Students College in Palu City
}

\author{
Sri Dewi Lisnawaty ${ }^{1}$ \\ \{sridewi_liesty77@yahoo.com ${ }^{1}$ \} \\ Institut Agama Islam Negeri (IAIN) Datokarama Palu, Palu, Central Sulawesi, Indonesia ${ }^{1}$
}

\begin{abstract}
The sexual behavior of dating students college in Palu City nowadays tends to adopt western culture, where their dating behavior is implemented through physical touches such as holding hands, hugging, kissing, groping each other, making out to intercourse as what married couple do. Their dating behavior which tends to be permissive resulting in non-marital pregnancy. The aim of this study is to describe the social process on sexual behavior of dating student in the city of Palu. The method of the research was qualitative descriptive research approach that produces descriptive data about spoken and written words and the behavior of the people studied. Data collection techniques are carried out through observation, interviews, research instruments and documentation. The results of the study found that the social process of dating students' sexual behavior is generally carried out based on the stages of physical intercourse, starting from hugging, holding hands, dry kissing, wet kissing, hugging, holding or touching private parts, petting, oral sex, and frequent intercourse. These actions were done freely because the social environment enables the students to commit sexual behaviors without considering the consequences of their deviant behaviors.
\end{abstract}

Keywords: Social process, sexual behavior, dating students.

\section{Introduction}

Observing the phenomenon that occurs in Indonesia today, there are so many problems arise, one of them is the problem of sexual intercourse amongst adolescent, where their dating behavior became so severe because many get lost in "dark paths", forgetting their time and age, to study or acquire knowledge. Instead of knowledge, they are lost in pursuing "forbidden pleasure", and few students become victims of their sexual behavior in dating. The freedom in sexual behavior in Indonesia is currently increasing, this phenomenon can be found in observations of daily life and in the mass media, ranging from dating without norm boundaries, non-marital sexual relationship, pregnancy, abortion, and to live together without any legitimate marital ties. This condition is not only done by adults, but also by adolescents [1].

Phenomenon in Semarang, a study of 1086 respondents of Junior High School students found that 4.1 percent of young men and 5.1 percent of young women had had sex. The same year, 
Tjitarra surveyed 205 adolescents who had unwanted pregnancy. The survey conducted by Tjitarra also revealed that the majority of them have high school education and above, 23 percent of them are aged 15-20 years old, and 77 percent are aged 20-25 years old, (Satoto; in Yeni 1998). Research Center for Health Research, University of Indonesia (UI) mentioned that 650 thousand teenagers are not virgins. The research was conducted in 2010/2011. If you add Tangerang and Bekasi, 20.9 percent of teenagers had non-marital pregnancy. This figure increases when the research is carried out nationally [2].

Dating is the main object in venting the sexual desire of adolescents. Nearly 50 percent of couples who are dating have done it, and the saddest thing is that averagely, it is done by teenagers/students. From this, it can be described that there is a shift in the culture of modesty today, especially for young people dating both in Indonesia in general and in the city of Palu in particular [1].

A community leader named H. Umar Syamsuddin expressed that the sexual behavior of dating adolescents in Palu City has now reached a level that is quite sad for the community. This gave a strong encouragement to the researcher to research the sexual behavior of dating students in Palu City, especially in West Palu District. The phenomenon of rampant sexual behavior among students that occurs in the West Palu area, where people around the boarding house often find birth control pills and used condoms in the trash, and it is likely that these condoms have been used by students who have sexual behavior with their boyfriends in the boarding room. The results of the researcher's initial observations revealed that around 6 (six) students had engaged in sexual behavior in dating, and among them there were those who ended up getting married while being pregnant and finally stopped (on leave) from college, but this study purposively selected 5 ( five) students who are dating and have engaged in sexual behavior in dating (non-marital sexual relationship).

From the phenomenon of student dating sexual behavior, the researcher aims to explore deeply the social process of sexual behavior of dating student in the city of Palu

\section{Method}

The research method is descriptive qualitative with phenomenological approach, because it deals with human behavior which includes what is said and done as a result of the way humans define their world. (Bernard Raho, 2007). The location of this research is the city of Palu, especially in the West Palu District as a research location because the students who are the subjects of the research live near the campus, thus making it easier for researchers to be able to seek deeper information. The data collection technique is observation, interview and documentation. The data analysis technique was carried out qualitatively with stages (1). Examining all data obtained by reading, studying and understanding it, (2). Reducing data by means of abstraction, namely analyzing and summarizing the essence of the data, (3). Arranging the data in units or classifications, (4). The units were then categorized while coding takes place, (5). Checking data validity. 
The recommended data validation techniques are participation extension, observation persistence, triangulation, peer checking, negative case analysis, reference adequacy, member checking, detailed description, and audit trail [3].

\section{Result and Discussion}

\subsection{Social Process on Sexual Behaviour of Dating Students}

Humans are social creatures who throughout their life socialize with other people in the process of interaction. Social processes are ways of relating that can be seen if individuals and groups meet and determine the system and form of this relationship or what will happen if there are changes that cause the disturbance in the existing ways of life [4].

If two or more people have a relationship with each other, it means that they have interacted, and then there will also be the social process [5]. Thus the social process is a relationship between fellow humans in a community environment that creates an attachment of interests that creates social status. Adolescence is a period of transition from children to adults. Some environmental changes make a difference in this transition period. For example, a student as a late teenager undergoes a transition from high school to university that involves a movement towards a larger, impersonal school structure; interaction with peer groups from areas with more diverse ethnic backgrounds.

The following is the social process that prompts the sexual behavior of dating students in Palu City, based on the findings of this study as follows:

\subsection{1}

Social interactions that are carried out without the supervision of parents or the community around the place of residence provide freedom and opportunities for adolescents to do or practice all their curiosity, including sex. These sexual urges will increase with the spread of information through mass media such as VCDs, stencil books, photos, magazines, the internet, and others. Increased sexual drive is supported by curiosity as well as social conditions and the attitude of the community around the student residence who does not care about the conditions of each resident resultingin providing opportunities for teenage students to have premarital sex.

Based on the results of an interview with one of the informants, it was found that various kinds of risky sexual behavior such as holding hands, dry kissing, wet kissing, hugging, holding or touching private parts, petting, oral sex, and having intercourse are often done because of the freedom in the social environment and students having ample opportunity to commit sexual deviations without thinking about the consequences of these deviant actions. The non-marital relationship that they have has become a trend both among teenagers and among students, especially students in Palu City.

To facilitate an understanding of the description of the form of sexual behavior in dating, it is described in Table 1 below.

Table 1. Social Process of Sexual Behavior of Students

\section{No Forms of Sexual Information about sexual}




\section{Behavior}

\section{activity during dating}

\section{Haven't Done}

Already Done

\begin{tabular}{lcc}
\hline 1 & Holding Hands & $\checkmark$ \\
2 & Dry kiss & $\checkmark$ \\
3 & Wet Kiss & $\checkmark$ \\
4 & Hugging & $\checkmark$ \\
5 & Touching Private Parts & $\checkmark$ \\
6 & Oral sex & $\checkmark$ \\
7 & Petting & $\checkmark$ \\
8 & Intercourse & $\checkmark$ \\
\hline
\end{tabular}

Source: Research Result, Agustus 2018

Based on Table 1, an illustration is obtained that the social process of dating students College sexual behavior every time they meet, they have already carried out sexual behavior activities such as holding hands, dry kissing, wet kissing, hugging, touching private parts and oral sex, petting and having intercourse. Sexual behavior is carried out both in boarding houses and in public places such as malls and entertainment beaches. It is clear from table 1 that it also shows that sexual activity carried out by the respondent includes all forms of sexual behavior in dating. The results of the previous interview also explained that the respondent had had an intimate relationship.

\subsection{2}

Based on the information obtained about the social process of sexual behavior with their partners in dating, it is explained. Based on the information that the social process of sexual behavior carried out by students in relating with their partners, starting from holding hands, dry kissing, wet kissing, hugging, touching private parts to rubbing the genitals to orgasm. The sexual behavior of teenage students as described by Hurlock regarding the stages in premarital sex behavior, namely the pattern of intimacy during dating which can end in premarital sexual behavior starting from kissing, light making out, heavy making out, and then intimate relationships. Initially dry kissing, after that wet kissing, kissing the neck (necking), after that rubbing each other's genitals (petting), trying to rub the penis against the lips of the vagina and so on until full intercourse [6].

\subsection{3}

Based on the results of the interview and the description of table 5.3 above, it can be concluded that the social activities of dating carried out by informant F.A (19 years old) with her 
partner reached climax until they have sex like husband and wife. Deviant social behavior has become part of their needs which they cannot avoid even though the consequence of their deviant behavior is that they are isolated from close relationships with local community members. Adolescents who engage in free sex are considered delinquent teenagers and are classified as socially disabled children who suffer from mental disabilities, thus displaying anti-social behavior or abnormalities in their behavior. This behavior is considered by the community as behavior that violates social, religious and legal norms in society. This is explained by Kartini Kartono that delinquent teenagers are also referred to as socially disabled children. They suffer from mental disabilities due to social influences in society, where their behavior is considered by society as a disorder and is called "delinquency". It is also emphasized in the Bakorlak Inpres no: 6/1977 guidebook 8 , it is said that juvenile delinquency is an anti-social adolescent behavior disorder/action that violates social norms of religious norms prevailing in society [7].

\subsection{4}

Socio-economic development gives an influence for students to associate themselves with the modern technology and in order to fulfill it, not a few of them have to take shortcuts to sacrifice themselves to have non-marital sex just as a reward from their partners of getting an iPAD or Mobile phone. This phenomenon is caused by inadequate economic factors of parents. What they did unconsciously has deviated them from the normal social process of sexual behavior among students

Based on the results of the interviews and the description of the table above, it can be concluded that deviant social behavior is carried out by the F.R.S informants in dating due to higher economic needs resulting in a give and take relationship as described in social exchange theory.

According to this theory, individual enter into exchange relationships with other people because from them they get a reward. in other words, exchange relationships with other people will produce a reward for them. Social exchange theory also sees that between behavior and the environment there is a reciprocal relationship. Because our environment generally consists of other people, we and these other people are seen to have behaviors that influence each other. In this relationship, there are elements of reward, sacrifice (cost) and profit. Rewards are everything that is obtained through sacrifice, sacrifice is all things that are avoided, and profit is the reward reduced by sacrifice [8].

The theory of social exchange developed by Thibault and Kelley assumes that the basic form of social relations is a commercial transaction, where people relate to other people because they expect something to meet their needs. This theory is based on the exchange of rewards (gifts) and costs in order to increase the value of the results of the communication process that occurs individually in the process of interpersonal communication. People will try to reduce costs and at the same time will maximize the rewards (profits that occur as a result of the interpersonal communication process) which is based on efforts to develop results that may be received by each party. When the results of this communication are felt to be enlarged or increased, we try to open and develop a narrower pattern of communication relationships with that person [9].

Apart from this theory, social processes that are influenced by globalization that cannot be avoided by anyone greatly affect one's social life. Because globalization includes all aspects of human life, from economy, ideology, politics, to technology. Because of this condition, the 
association of teenage students today is no longer in accordance with social norms that characterize a modest personality but rather promiscuity where they deliberately or compulsively engage in deviant sexual behavior ranging from holding hands, hugging and kissing to doing intercourse as expressed by Sarwono on premarital sexual behavior starting from hugging and holding hands, kissing, touching breasts, touching genitals and having sexual intercourse [10].

\subsection{5}

Nowadays promiscuity that leads to premarital sex behavior (dating, holding hands, kissing cheeks, hugging, kissing lips, touching breasts on top of clothes, touching breasts under clothes, touching genitals on top of clothes, touching genitals on under the pants, and having intercourse) has become something common, even though it shouldn't occur (Samino, 2012). Premarital sexual behavior carried out by adolescents originates from the emergence of "chemistry" (attraction) towards the opposite sex as a result of sexual development. This attraction invites adolescents to establish a romantic relationship, where in this romantic relationship adolescents begin to develop forms of sexual behavior together with the increasing sexual urges which lead to desires that are not easily understood by adolescents (Andayani and Setiawan, 2005). Social change begins to appear in the perception of society, which initially believed that sex as something sacred has become something that is no longer sacred, now sex has generally occur in the society. Coupled with the culture of sexual permissiveness in the younger generation, it is illustrated by dating couple who increasingly open up opportunities for deviant sexual acts as well as the existence of sexual freedom has hit the lives of people who have not yet married. Even premarital sex activity occurs among adolescents and students who are undergoing a cultural process by living up to scientific values [11].

\subsection{6}

The description of sexual behavior on students that has been shown above also shows the informants' views or values on sex which are increasingly permissive so that the informants tends to do things that increasingly involving themselves in physical relationships with the opposite sex. This is in accordance with what was stated by Pangkahila dalam Prawirodihardjo which is one that makes someone engage in premarital sex behavior is a permissive environment, because in environmental conditions like this, supervision is usually less strict so that the punishing effect is nonexistent and they tends to repeat it [12]. Again, as explained by George Homans (Ritzer, 2010; Bambang, 2012), the social exchange relationship carried out by humans can be explained through six basic proportions, including the Proposional success [13]. "In every action, the more often a particular action gets rewarded, the more often he will do that action ". This means that if someone succeeds in getting a reward (not getting punished) then that person tends to repeat the action.

Furthermore, Bechteren proposed the theory of instrumental behavior or Bechteren's avoidance and escape learning theory. Pavlov developed the Kinble Law Of Reinforcement. and Thorndike express the Law of Effect and Thorndike's law of Exercise [10]. The principles of these theories and laws are: If the stimuli give a positive effect or give rewards (rewarding), then the reciprocal behavior towards the stimuli will be repeated on other occasions where the same stimulation arises. Conversely, if the stimulation has a negative effect (punishing), the reciprocal relationship will be avoided at other times. 
The role of J.B. Watson in the development of the theory of reciprocity is to strengthen it into a movement which he named the theory of Behaviorism. This was done by presenting a working paper entitled psychology as the behaviorist views it (Watson, 1913). It is in this study that the theory of reciprocity develops rapidly.

\section{Conclusion}

Based on the results of the discussion that has been described above, it can be concluded that the social process of sexual behavior of dating student that deviates from the teachings of the Islamic religion starts from hugging, holding hands, dry kissing, wet kissing, hugging, holding or groping private parts, petting, oral sex, and sexual intercourse. Meanwhile, the social process of sexual behavior of dating student which is based on Islamic teachings is a process of Taarf which has limitations to avoid adultery. The limitations according to Islamic law include the following: (1) Not committing an act that can lead us to adultery, (2) Not touching a woman who is not one's Muhrim (3) Not being alone with the opposite sex who is not one's Mahram (4) Lowering one's gave to avoid lust (5) Shielding the Aurat.

\section{References}

[1] Lisnawaty S. D., "Hubungan antara Kecerdasan Spiritual dan Motivasi Berprestasi dengan Perilaku Seksual Remaja dalam Berpacaran di SMAN 4 Palu," Fakultas Psikologi Universitas Gadjah Mada, 2006.

[2] M. T. Gani, "Remaja di Kota Makassar (Studi Kenakalan Remaja di Kecamatan Tamalatea, Panakkukang dan Rappocini)," Pascasarjana Universitas Negeri Makassar, 2009.

[3] L. J. Moleong, Metode Penelitian Kualitatif, Edisi Revi. Bandung: PT. Remaja Rosdakarya, 2010.

[4] S. Soekanto, Remaja dan Masalah-masalahnya, sebab musabab dan pemecahannya. Jakarta: Penerbit BPK Gunung Mulya, 2012.

[5] Soetjiningsih.C.H., "Faktor-Faktor yang Mempengaruhi Perilaku Seksual Pranikah pada Remaja," Fakultas Psikologi Universitas Gadjah Mada, 2008.

[6] F. Betha, "Perilaku Seksual Pranikah Ditinjau dari Intensitas Cinta dan Sikap terhadap Pornografi pada Dewasa Awal," J. Psikol., 2011.

[7] Kartono K, Patologi Sosial, Jilid 1. Jakarta: Rajawali Pers, 2011.

[8] M. Hasan, "Perspektif dalam Psikologi Sosial," 2008. http://meiliemma.wordpress.com/2008/01/27/teori-pertukaran-sosial (accessed Nov. 17, 2013).

[9] Rizky Aulia Y., "Teori Pertukaran Sosial (Social Exchange Theory)," 2013. http://teoripertukaransosial.htm. (accessed May 25, 2014).

[10] Sarwono, Teori-Teori Psikologi Sosial, Edisi Revi. Jakarta: Rajawali Pers, 2011.

[11] Salisa Anna., "Perilaku Seks Pranikah Dikalangan Remaja," Fakultas Kedokteran Universitas Sebelas Maret Surakarta, 2010.

[12] Prawirodihardjo L., "Perilaku Seks Bebas Remaja di Kota Makassar," Pascasarjana Universitas Negeri Makassar, 2013.

[13] Ritzer George, Sosiologi Ilmu Pengetahuan Berparadigma Ganda. Jakarta: PT. RajaGrafindo Persada, 2010. 
